\title{
Research and Experimentation
}

TN THIS section G. Flint Purdy, librarian of Wayne University, introduces his first 1 report on research and experimentation.

One of the avowed objectives of College and Research Libraries is to foster investigation of the problems of college, university and reference librarianship. In line with that objective, we hope to keep you informed concerning pertinent research and experimentation, completed and in progress. The list presented below represents an embryonic beginning. We are attempting to organize machinery for the periodic collection of complete information concerning projects under way or finished. We solicit your aid in procuring such information.

The list of studies which follows has been compiled from reports by libraries and library schools. Most of the studies listed have probably been completed and reported as theses.

\section{Historical and Bibliographical Studies}

Doneghy, Frances V.

A study of the present reference value of eighteenth century English and American periodicals and of the extent and adequacy of existing indexes to them. (Columbia)

Duncan, Ruth B.

A history of the library of George Peabody College and its predecessors from 1789 1909. (Peabody)

Esterquest, Ralph T.

The war-time attitudes and activities of American libraries, 1914-1918. (Illinois)

Hoole, William Stanley.

The Carnegie Corporation, the General Education Board, the Rosenwald Foundation, and college and university libraries in the south, 1929-I939. (Chicago)

Leek, Marjorie $\mathrm{H}$.

Media for studying contemporary book reviews in English literature, I 800-I 850 . (Columbia)

Leonard, Ruth S.

A bibliographical evaluation of the United States copyright records, I790-1870, as illustrated by the copyright records of the United States district court of Massachusetts. (Columbia)

Louisiana State University.

An annotated bibliography of Louisiana pamphlets, $1860-1877$, found in the collection of the Hill Memorial Library. (Author not reported)

Minick, A. Rachel.

History of printing in Maryland, I79II800, with a bibliography of Maryland imprints. (Columbia)

Ostrowsky, Clara.

Study of American festive publications and a check list of festschrift holdings of libraries in New York City and possibly in the Library of Congress. (Columbia)

Snodgrass, Isabelle S.

A study of American musical periodicals, I786-1900. (Columbia)

\section{Reading Studies}

Baum, Elizabeth $M$.

The reading interests of Beaver College alumnæ as a means of guidance to undergraduate reading interests. (Columbia)

\section{Bell, Martha S.}

A study of the records of all library loans (except loans from the reserved collection) made to a class of Randolph-Macon Woman's College students during four years in college. (Columbia)

Jackson, Evalene Parsons.

The attitudes toward the Negro race of southern white children as affected by reading fiction. (Emory) 
Killibrew, Ruth.

Survey of periodical reading tastes and habits of junior college students (Kansas City [Kan.] Public Library)

Reich, Evalyn.

A technique for finding the relationships between the concerns and the reading of out-of-school young adults. (Illinois)

Tiplady, Charlotte $M$.

Reading and reading interests of alumnæ of Hollins College, Va. (Columbia)

\section{Administration}

Brindley, Mary E.

A study of college and university library handbooks. (Columbia)

Brown, George B.

An investigation into relationships between librarians and law book publishers and booksellers. (Illinois)

Brown, Helen $M$.

A study of conditions contributing to the efficiency of student assistants in a selected group of college libraries. (Columbia)

Coleman, L. Zenobia.

What changes are needed in the organization and administration of the college library to make it an effective instructional tool in a small liberal arts college which has adopted the new curriculum? (Columbia)

\section{Erlandson, Ruth $M$.}

An analysis of the questions asked at the information desk of the university library, as a basis for the preparation of a library handbook for students. (Illinois)

\section{Miller, Marvin A.}

Professional and non-professional work in the college library: a work analysis. (Columbia)

\section{Mount Holyoke College Library.}

"The average cost of books per volume by department ordering. Records to date cover three years and show variations of $\$ 1.75$ for English to $\$ 7.97$ for chemistry; and a general average of $\$ 3.45$."

Library information test.

"A study of circulation by classes, cov- ering the past twenty years in an attempt to learn the probability of circulating books purchased prior to 1920 as compared to more recent accessions. Of the books examined 24 per cent have not circulated since 1920; of these 42 per cent were acquired prior to that date."

Oberheim, Grace M.

Measuring abilities of student assistants in the college library. (Columbia)

Watson, Parepa R.

A study of library reports in Negro colleges and universities. (Columbia)

\section{Book Selection}

\section{Borneman, Helen I.}

Are the present methods of book reviewing employed by historical periodicals sufficient to enable the college librarian to make a wise choice in book selection? (Columbia)

Doggett, Marguerite $V$.

The extent to which book reviews in certain biological journals meet the need of college library book selection. (Columbia)

Dunn, Sister Helen.

What constitutes a minimum basic list of Spanish books for a Spanish curriculum in a four-year liberal arts college? (Columbia)

Falvey, Daniel P.

A selection of philosophy books for the Catholic college library. (Columbia)

Hepinstall, Frances.

A study of the book selection methods used in the normal school and teachers college libraries of New York state. (Columbia)

Rogan, Marie J.

An investigation of the book reviewing qualities of a selected list of journals for college library book selection in the field of English and American literature for 1938. (Columbia)

Steele, Rea J.

To study the book reviewing adequacy of five professional periodicals in the field of higher education for book selection in the college library. (Columbia) 


\section{Reference Tools and Departments}

Cord, Madeline.

History of the reference department of the University of Illinois Library. (Illinois)

Fisher, Elizabeth.

Johnson's New University Cyclopaedia; its history and uses to be made of it today. (Columbia)

Johnson, Elizabeth $\mathrm{H}$.

A study of Wallace's Dictionary of Canadian Biography with a view to ascertaining its value as a basic dictionary of Canadian biography. (Columbia)

\section{Mclntyre, Helen.}

A comparative study of certain American and English dictionaries of quotations. (IIlinois)

Ross, Jean L.

An historical and critical study of the National Cyclopaedia of American Biography. (Columbia)

Stubbs, Marian.

A comparison of the biographical material in the Americana Annual and the New International Yearbook, to determine the value of each in that field. (Columbia)

\section{Documents}

Ayrault, Margaret W.

The handling of the processed publications of the federal government by the catalog departments of certain large public and university libraries. (Columbia)

Boyd, Anne M.

United States government publications. rev. ed. (Illinois)

Cheney, Frances N.

Historical and bibliographical study of the administrative departments of the state of Tennessee. (State documents) (Columbia)

Jackson, Eugene B.

United States government publications of value to an engineering library. (Illinois)

Reuss, Dorothy.

Federal publications relating to the metropolitan area of Cleveland. (Illinois)
Saylor, Cerilla E.

Official publications of the state of Missouri. (Illinois)

\section{Technical Processes}

Bond, Ethel.

Uniform headings for anonymous classics, sacred books, etc. (Illinois)

Elmer, Minnie.

An investigation of the catalogers' reference tools for music collections in large public and university libraries. (Columbia)

Gemmell, Hertensia.

Methods used in the cataloging of serial publications of societies and institutions in small college libraries. (Columbia)

Iskenderian, Yerchanik.

A study in cooperation in the cataloging of serials in large public and university libraries. (Columbia)

Jones, Helen J.

How are secondary cards for different editions of the same books handled in the catalogs of a selected list of college and university libraries? (Columbia)

Moore, Kay K.

A study of the cataloging rules for entry of American colleges and universities, with recommendations applied to a directory of colleges, universities, teachers colleges, and normal schools in the middle Atlantic states. (Columbia)

\section{Mount Holyoke College Library.}

Techniques for reclassifying department libraries.

Rushing, Naomi J.

The organization, classification and cataloging, exclusive of subject headings, of books by and about the Negro as a special collection. (Columbia)

\section{Shubert, Esther Marian.}

Cataloging problems relating to anonymous classics concerning the King Arthur stories of Lancelot. (Illinois)

Simon, Beatrice V.

Manual on care and treatment of serial publications in college and research libraries. (McGill) 
Vibbard, Dorothy A.

An investigation of the treatment of "rush books" in catalog departments of public and university libraries of more than 200,000 volumes. (Columbia)

Whitlock, Ruth L.

Cataloging headings for the official publications of the state of Wisconsin. (Illinois)

\section{Miscellaneous}

Allez, George C.

"A ten year study of the placement of the library school of the University of Wisconsin. The thing in which we are interested in this study is to determine the field of influence of our library school, both geographically and as far as types of libraries and positions are concerned. We hope to get from this study some information which will be helpful in the further revision of our curriculum." (Wisconsin)

Beach, Robert.

Book-extension work in eastern Kentucky; an historical survey and analysis, with special reference to the contribution of the Berea College Library. (Columbia)

Engle, Virginia.

A study of the implications of the maintenance at Berea College Library of a special collection on the southern Appalachian Mountain region. (Columbia)

Harkins, Eleanor.

A study of the activities of librarians in the university and in the senior colleges of the state of Mississippi. (Columbia)

Manlove, Ruth T.

The use which public and college and university libraries are making of the motion picture in adult education programs. (Columbia)

Milczewski, Marion A.

Personality rating of library school students. (Illinois)

Mount Holyoke College Library.

The role of the library during the reading period. 


\section{Public Administration and Personnel Work}

T UCILE L. KECK calls attention to the following publications in the field of public 1 administration and personnel work that are significant from the standpoint of the direction of large libraries because they develop or embody guiding principles of administration.

Public Personnel Review. Published by the Civil Service Assembly of the United States and Canada. Chicago. Vol. I, No. I, April 1940. Quarterly. $\$ 5$ a year.

A new journal dealing with administrative and technical problems in the field of public personnel administration. The first number contains articles by Leonard D. White, H. Eliot Kaplan and others.

Progressive Office Management Policies. 1939. 44p. \$I. (Office Management Series, No. 86.)

Attitudes and Emotional Problems of Office Employees. 1939. 34p. 6oc. (Office Management Series, No. 87.)

Employee Selection; Salary Administration. 1939. 40p. 75c. (Office Management Series, No. 88.)

Employee Rating; Regularization of Employment; Group Medicine. 1939. 47p. \$I. (Personnel Series, No. 39.)

Four pamphlets of the American Management Association discussing various problems of office management and personnel.

Davis, Hazel. Personnel Administration in Three Non-Teaching Services of the
Public Schools. Bureau of Publications, Teachers College, Columbia University, 1939. 323p. \$2.50.

A study to determine whether or not approved personnel procedures in administration tend to be associated with evidences of adequate performance in the non-teaching services in the public schools. The book states a series of principles of personnel administration which have been developed in school administration, and observes that those city school systems which adopt such principles tend to be above the average in performance.

Rathert, A. R. Public Employee Credit Unions. Minnesota State Federation of Teachers, April 1940. I8p. IOc.

Michelmore, Laurence. University InService Training for Public Employees. School of Public Affairs and Social Work, Wayne University, Detroit, 1940. 16p. 20c. (Detroit Bureau of Governmental Research, Inc., Memo No. I65.)

This is a record of the training of public employees in the Detroit area at Wayne University. 


\section{New Periodicals}

$\prod_{\text {HE following annotated list of recently launched periodicals has been contributed }}$ by Carolyn F. Ulrich, chief, Periodicals Division, New York Public Library.

Arkhitektura Radyans'koi Ukrainy.

L'Architecture de l'Ukraine Soviétique. Organ of the Spilka Radyans'kikh Arkhitektoriv. Poushkinskaiya I, Kiev, RSSU. No. I, Jan. 1939. Monthly. Approximately $\$ 3$ a year.

Text in Ukranian. Contains plans and illustrations.

Australian Jewish Historical Society. Journal and Proceedings. 2 Castlereagh Street, Sydney, New South Wales. Vol. I, No. I, 1939. Frequency not given. Ios. a year.

Bill of Rights Review. Published by the Bill of Rights Committee of the American Bar Association, 3I Nassau Street, New York City. Vol. I, No. I, Summer 1940. Quarterly. \$I a year.

Its aim is "to disseminate information generally concerning our constitutional liberties. contains a section, "Notes and Cases" which reviews
"important current situations and decisions in the "important current situations, and decisions in the field of civil liberties. ". Among contributors
are: Zechariah Chafee, Jr., Langdell professor of
law, Sam Bass Warner, professor of penal legislation and administration (both at the Harvard Law School), Charles A. Beard, noted historian and teacher, and John W. Davis, former ambassador to Great Britain and former president of the American Bar Association. Contains reviews of current books and articles.

Chaski; organo de la Asociación Peruana de Arqueología. Published by the Museo de Arqueologia de la Universidad de San Marcos, Lima, Peru, Vol. I, No. I, Jan.Feb. 1940. Frequency and price not given.

Contains maps of the sites of archeological research, photographs and detailed dimensional sketches of ancient dwellings, and illustrations depicting the decorative art of the early people as shown on vases,
textiles, obelisks, etc. Includes book reviews and textiles, obelisks, etc.
bibliographical notes.

Ciencia; revista hispano-americana de ciencias puras y aplicadas. Editorial Atlante, S.A., Artes, 53, México, D.F. Vol. I, No. I, Mar. 1940. Monthly. \$3 a year. Designed for either the scientific worker or the lay reader, who wishes to keep informed of the progress of science in all its branches. Contains abstracts, book reviews and bibliographies at the end of each article.
College English. Official organ of the National Council of Teachers of English. University of Chicago Press, 5750 Ellis Ave., Chicago. Vol. I, No. I, Oct. 1939. Monthly (Oct-May). \$3 a year.

Articles, criticisms, and surveys of interest both to the student and the teacher of college English. Contains reviews of books and periodicals.

Contemporary Law Pamphlets; international in scope. Published by the New York University School of Law, Washington Square East, New York City. Irregular. \$I a pamphlet.

Series I: General. No. I, 1937.

Series 2: Legal Philosophy. No. I, 1939.

Series 3: Comparative Law. No. I, 1939.

Series 4: Law and Business. No. I, 1940.

Series 5: International Law. No. I, I940.

Series 6: Pending Legislation. No. I, 1940.

Current Thought; journal of progressive ideas. Published by Parimal Ghosh. C/o The Comilla Banking Corporation Ltd., 4, Clive Ghat Street, Calcutta. Vol. I, No. I, Apr. 1939(?) Quarterly. I4s. a year.

An independent journal for discussion of social problems. Hindu editorial board.

Design; an Australian review of critical thought. Published by John Gartner, the Hawthorn Press, 93 Tooronga Road, Hawthorn East, Victoria. No. I, Jan. 1940. Quarterly. 5s. a year.

Attractive format and promising in scope.

Documentary News Letter. Published by the Film Centre. 34 Soho Square, London, in association with the American Film Center, New York. No. I, Jan. 1940. Monthly. 3d. a copy.

Analyzes and reports on activity in the production of documentary films in Great Britain and other countries. Contains book and film reviews.

Epigraphica; rivista italiana di epigrafia.

Casa Editrice Ceschina, Via Gesù, 23, Milan. Vol. I, No. I, Jan.-Mar. 1939. Quarterly. L.Ioo a year.

Contains articles on the study of ancient inscrip- 
tions, i.e. "Results of the Revision of the Text of the Capitoline Records," "Catalogue of the Epigraphic Code in the Milan Library," "An Imperial Inscription of Reate," "The International Congress of Epigraphy at Amsterdam, r938." Contains bibof Epigraphy at Amsterdam, 1938." Cont
liography, book reviews and illustrations.

España Peregrina. Published by the Junta de Cultura Española, Dinamarca, 8o, México, D.F. Vol. I, No. I, Feb. 1940. Monthly. Io pesos a year.

Represents exiled Spanish intellectuals who favor Republican Spain. Includes poems, essays, scientific and cultural works, and book reviews.

Farm and Home Science. Published by the Utah Agricultural Experiment Station, Logan, Utah. Vol. I, No. I, Mar. 1940. Quarterly. Price not given.

Practical information derived from experimentation on subjects connected with agriculture. Illustrated.

Folios of New Writing. The Hogarth Press, 37 Mecklenburgh Square, London. Vol. I, No. I, Spring 1940. Irregular. 5s. an issue.

Continuation of New Writing. A significant guide to modern literary trends in contemporary British prose and verse. Published in book form.

Forestry Abstracts. Published by the Imperial Forestry Bureau, Oxford, England. Vol. I, No. I, I939. Quarterly. 20s. a year.

Abstracts from leading publications of all countries. Also includes a few original articles.

French Digest; France in review. French Digest, Inc., 444 Madison Ave., New York City. Vol. I, No. I, Mar.-Apr. 1940. Bimonthly. \$I a year.

Text in English with a section in French. Condensations of current French books and articles selected from French periodicals and newspapers. Pocket size. Illustrated.

Indian Farming. Issued by the Imperial Council of Agricultural Research, Civil Lines, Delhi. Vol. I, No. I, Jan. 1940. Monthly. Rs. 6 a year.

Replaces the bimonthly Agriculture and Livestock in India. The aim of the new magazine is to present scientific information in a non-technical form about Indian agriculture and animal husbandry. Contains book reviews and good illustrations.

International Journal of Agrarian Affairs. Published by Oxford University Press, 3 Magpie Lane, Oxford, England. Vol. I, No. I, Oct. I939. Semi-annual. 3s. 6d. a copy.

Each number as a rule will deal with one general economic or social problem of agriculture. It will discuss these problems on an international basis and from all angles.

Mental Health. Published by the Central Association for Mental Welfare, Child Guidance Council and National Council for Mental Hygiene. 24 Buckingham Palace Road, London. Vol. I, No. I, Jan. 1940. Quarterly (?) Iod. a copy.

Replaces Mental Hygiene and Mental Welfare. Contains good book reviews.

Modern Language Quarterly. University of Washington Press, Seattle. Vol I, No. I, Mar. 1940. Quarterly. \$2 a year.

Scholarly studies in the English, American, Germanic, and Romance languages and literatures. Reviews of current publications by professors from the leading universities.

Phylon; the Atlanta University review of race and culture. Atlanta University, Atlanta. Vol. I, No. I, I940. Quarterly. \$I a year.

Survey of the field of race and culture with special emphasis on the Negro ace. Edited by $W$. E. B. Du Bois. Contains brief book reviews and a list of articles in periodicals.

Psicotecnia; organo del Instituto $\mathrm{Nacional}$ de Psicotecnia. Plaza de Santa Bárbara, Io, Madrid. Vol. I, No. I, Oct. 1939. Quarterly. I5 pesetas a year.

Covers the field of applied psychology. Contains graphs, charts and book reviews.

Public Personnel Review. Published by the Civil Service Assembly of the United States and Canada, I313 East 6oth Street, Chicago. Vol. I, No. I, Apr. 1940. Quarterly. \$5 a year.

Deals with the development and the improvement of administrative and technical problems in the field of public personnel administration. Contributors include: Leonard D. White, professor of public ad. ministration, University of Chicago; Albert H. Aron son, chief of state technical advisory service of social security board.

Quarterly Bulletin of Chinese Bibliography. Published jointly by the Chinese National Committee on Intellectual Cooperation and the National Library of Peiping, Kunming, Yunnan, China. New series Vol. I, No. I, Mar. 1940. Quarterly. English edition. \$2 a year.

This is a revival of The Quarterly Bulletin of Chinese Bibliography which ceased in Dec. I937. "The purpose of the bulletin is to record recent advances in research as reflected in Chinese books and periodicals." Books, government publications 
and periodicals are entered in Chinese and in European languages. There is also a section on European hooks translated into Chinese.

Revista Mexicana de Sociologia. Published by the Instituto de Investigaciones Sociales de la Universidad Nacional, República de Cuba, 92, México, D.F. Vol. I, No. I, Mar.-Apr. 1939. Bimonthly. 50c a copy. Contains abstracts and book reviews. Illustrated.

Revue Baltique; organe de la collaboration des Etats Baltes. Published by the Estonian-Latvian-Lithuanian Co-operation Bureau, Tallinn. Vol. I, No. I, Feb. 1940. Three times a year. 2.50 EKR a copy. Text in English, French and German.

Purpose is "to be a connecting link between the Baltic peoples, to express their public opinion on their fundamental problems as well as current affairs.." in the rapprochement of the Baltic States.

Turnbull Library Record. Published by the Friends of the Turnbull Library, Wellington, New Zealand. Vol. I, No. I, Jan. 1940. Frequency and price not given.

"It will be the vehicle for more precise particulars of books, manuscripts and other records, and the publication of shopt texts of importance to the research worker in several fields."
Voici; la France de ce mois. Published by Sociéte Nouvelle Sequana, 33 rue de Naples, Paris. Vol. I, No. I, Feb. I940. Monthly. \$2 a year.

Digest of current French literature. Contributors include: Georges Duhamel, Paul Valery, Edouard Herriot, and Jules Cambon.

Wood Technic with which is combined Hardwood Record. The Hardwood Company, 537 S. Dearborn Street. Chicago. Vol. I, No. I, Jan. 1940. Monthly. $\$ 2$ a year.

A trade paper that contains good articles on processing wood and its uses.

Zeitschrift für schweizerische Archaeologie und Kunstgeschichte. (Revue suisse d'art et d'archeologie. Rivista svizzera d'arte e d'archeologia.) Organ of the Verband der Schweizerischen Altertumssammlungen and of the Gesellschaft für Schweizerische Kunstgeschichte. Verlag E. Birkhäuser und Cie., Basel. Vol. I, No. I, 1939. Quarterly. Schweiz Fr. Io a year.

Text in French, German and Italian. Scholarly treatment of subject, beautiful format and excellent illustrations. 


\section{Current Reference Aids}

Compiled by the Subcommittee on Current Reference Aids of the Association of College and Reference Libraries: Louis Shores, chairman; Frances Neel Cheney, secretary; Mabel L. Conat; Louis Kaplan; Charles F. McCombs; James T. Rubey; Harold Russell; Anne M. Smith. The list of "Selected Foreign Language Reference Books of 1939" has been compiled by Mr. Kaplan.

Where prices are not listed they were unobtainable.

I. Reference Books, January I-July I, 1940

\section{oI6 General Bibliography}

Census of Medieval and Renaissance Manuscripts in the United States and Canada. Seymour De Ricci and W. J. Wilson, eds. Vol. I11, Index. Wilson, 1940. 222p. \$3.

Historical Records Survey, Tenn. Check List of Acts and Codes of the State of Tennessee, I792-1939; prepared by the Tennessee Historical Records Survey Project . . . Nashville, 1940. 21p. Free (Special Publications Series, No. 5)

Shaw, Charles B. A List of Books for College Libraries 1931-38. A.L.A., 1940. 284p. \$6.

Wilcox, Jerome K., ed. Manual on the Use of State Publications. A.L.A., I940. 342p. \$6.

\section{Library Science}

Association of Special Libraries and Information Bureaux. Report. Association, 1940. 5 s.

Contains "The Accessibility of British University Thesis Literature" by Dr. Luxmoore Newcombe; "The Imperial Institute as an Information Centre" y Sir Harry Lindsay; "Authors' Abstracts as an Aid to Documentation" by Sir Gordon Fulcher; and "Microphotography in 1939" by Dr. Leonard Sayce.

\section{I0o Philosophy and Psychology}

Ansbacker, H. L., ed. Abstract References of the Psychological Index I894-I928. American Psychological Association Inc., Ohio State University, Columbus. Send orders to Abstract References, 25 Claremont Ave., New York City.

Thomas, Milton H. A Bibliography of John Dewey, I882-1939. Columbia University Press, 1939. 246p. \$3.
200 Religion

Barborka, Geoffrey A. Gods and Heroes of the Bhagavad-Gita; a brief description of the mythology of ancient India as contained in the Bhagavad-Gita, including technical terms and explanations in the light of theosophy. Theosophical University Press, Point Loma, Calif. 156p. 75 c. Vine, W. E. Expository Dictionary of New Testament Words. Lo-Ser. Oliphants, 1940. 349p. 10s. 6d.

\section{Social Sciences}

Appel, Livia. Bibliographical Citation in the Social Sciences: a handbook of style. University of Wisconsin Press, Madison, I940. 30p. 6oc.

Boggs, Ralph S. Bibliography of Latin American Folklore. Wilson, 1940. Io9p. $\$ 1.50$.

Finland. Ministry of Foreign Affairs. The Development of Finnish-Soviet Relations. Harrap, London, 1940. 3s.

Great Britain. Parliament. Royal Commission on West Indies. West India Royal Commission 1938-39. Recommendations. H.M.S.O., 1940. 6d.

Keith, Arthur Berriedale. The Constitution of England from Queen Victoria to George VI. Macmillan, London, 1940. 2v. 30 .

League of Nations. Appeal by the Finnish Government. 6d. Supplementary Documentation Transmitted by Finland. 9d. Report of the Assembly. 6d. Allen \& Unwin, 1940.

\section{Philology}

Stanislawski, J. English-Polish and PolishEnglish Dictionary. Minerva Pub. Co., London, 1940. 90op. 10s. 6d. 
500 Natural Science

Appleyard, Rollo. The History of the Institution of Electrical Engineers, I87I193I. Institute of Electrical Engineers, London, 1940. I8s. 6d.

Camm, F. J., ed. A Dictionary of Metals and Their Alloys. Newnes, London, 1940. 245p. 5s.

The Chemists' Yearbook, 1940. E. Hope, ed. Chemical Publishing Co., Inc., New York, 1940. 1257p. \$6.

Karpinski, Louis C. Bibliography of Mathematical Works Printed in America through 1850 . University of Michigan Press, 1940. 697p. $\$ 6$.

The Meteorological Glossary; 3d ed., in continuation of the weather map, published by the authority of the Meteorological Committee ... Ist American ed. Chemical Publishing Co., Inc., New York, 25 Ip. \$3.

Rice, C. M. Dictionary of Geological Terms (exclusive of stratigraphic formations and paleontologic genera and species). Edwards Brothers, Inc., Ann Arbor, Mich., I940. 46ip. \$6. Paper. (Planographed)

Sherborn, Charles D., Comp. Where is the - Collection? An account of the various natural history collections which have come under the notice of the compiler between 1880 and 1939. Cambridge University Press, I940. I48p. 3s. 6d.

\section{Applied Science}

The First Printers and Their Books; a catalogue of an exhibition commemorating the five hundredth anniversary of the invention of printing. Elizabeth Mongan and Edwin Wolf, 2d, comps. The Free Library of Philadelphia, 1940. 94p. $50 c$.

Hünlich, Richard. Textile Fibres and $\mathrm{Ma-}$ terials: their properties and identification, with special reference to rayon and staple fibre. A. J. Hall, trans. H. P. Curtis, ed. Skinner, London, 1940. 222p. 8s. $6 d$.

\section{Art}

Brooke, Iris. Western European Costume. Seventeenth-mid-igth century and its re- lation to the theatre. Harrap, London, I940. I44p. I 8s.

Gore, L. L., comp. Index of Addresses Made at the Western Arts Association Conventions, I 894-1939. Western Arts Association, Indianapolis, I940. I 44p.

Greenwood, Frances A. Bibliography of Swimming. Wilson, 1940. 308p. \$4.25. Kolodin, [Irving.] The Metropolitan Opera I883-1939. 2d ed. Oxford University Press, I 940 . 649p. \$3.75.

Mayer, L. A. Bibliography of Moslem Numismatics, India Excepted. Luzac, 1940. I I 5p. 5s. (Oriental Translation Fund. New Series. Vol. 35)

Nathan, George Jean. Encyclopedia of the Theatre. Knopf, 1940. \$3.

"Critical discussion of present day American theatre and people connected with it."

National Association of Schools of Music, List of Books on Music. 2d suppl. The Association, B. C. Tuthill, Secretary, 3547 Shaw Ave., Cincinnati. 15c. (Bull. No. II)

Rickett, Edmond W. and Hoogland, Benjamin T. Let's Do Some Gilbert and Sullivan; il. by W. S. Gilbert. CowardMcCann, I940. \$2.50.

\section{Literature}

Chadwick, H. M. and N. K. The Growth of Literature. Vol. 3. Cambridge University Press, 1940. 945p. 35s. Vols. I-3, 1933-1940 (Vol. I, \$6; Vol. 2, \$9, or 30s. each)

Scholarly study on comparative literature.

\section{History}

Adams, James T., ed. Dictionary of American History. Scribner, 1940. 6v. $\$ 60$.

Argenti, Philip P. Bibliography of Chios. From classical times to I936. Oxford University Press, 1940. 836p. $42 \mathrm{~s}$.

Ekwall, Elert. The Concise Oxford Dictionary of English Place-Names. 2d ed. Oxford University Press, 1940. 57Ip. $\$ 5.75$.

Fuller, John F. C. Decisive Battles; their influence upon history and civilization. Vol. 2. From Napoleon the First to General Franco. Eyre \& Spottswoode, 1940. I6s. 
Milne, Alexander T., comp. Writings on British History, 1936: a bibliography of books and articles on the history of Great Britain from about A.D. 450 to 1914 , published during 1936. Cape, I940. 389p. I2s.6d. (British Historical Society.)

Salvatorelli, Luigi. A Concise History of Italy. Oxford University Press, I940. 688p. $\$ 5$.

\section{Biography}

Code, Joseph B. Dictionary of the American Hierarchy. Longman's, 1940. 425p. $\$ 3.75$.

Biographical sketches of American Catholic bishops, 1790 to date.

\section{Selected Foreign Language Reference Books of 1939}

(Serial publications, except those begun in 1939, are omitted. Prices given in foreign currencies are list; those given in American dollars are net.)

Académie de médecine, Paris. Index biographique des membres, des associés et des correspondants ... de décembre 1820 à juillet 1939. Masson, Paris, 1939. I45p. $81 \mathrm{c}$.

Académie des sciences, Paris. Index biographique des membres et correspondants ... de 1666 à 1939. Gauthier-Villars, Paris, 1939. 476p. \$1.38. Paper.

Amsterdam. Universiteit. Bibliotheek. Catalogus van de Bibliotheca Danica en van de overige Deensche en Ijislandsche Werken aanwezig in de Universiteitsbibliotheek. Stadstdrukkerij, Amsterdam, 1939. 524p.

Anuario prensa argentina. Sindicato prensa argentina, Buenos Aires, 1939. 304p. $\$ 1.50$.

Bandeira, M. Pequeno dicionário brasileiro da língua portuguesa. 2d. ed. rev. Civilizaçäo brasileiro, Rio de Janeiro, 1939. 1084p. \$25.

Bibliografia medico-biologica. Rassegna generale mensile der libri e della stampa periodica italiana di medicina e biologia. Bibliografia medico biologica, Roma, 1939. No. 1-2 (in progress). L. 120 a year.

Bibliothèque nationale. Catalogue général des manuscrits latins. Bibliothèque nationale, Paris, I939. T. I (in progress).

Bohatta, Hanns. Bibliographie der Breviere, 1501-1850. K. W. Hiersemann, Leipzig, 1939. 349p. M. 32.

Bohatta, Hanns and Funke, W. Internationale Bibliographie der Bibliographie. Klostermann, Frankfurt am Main, 1939. Lfg. I (in progress). \$1.28.

Bremond, Henri and Goyau, G. Manuel de la littérature catholique en France de 1870 à nos jours. Nouv. éd. Spes, Paris, 1939. 493p. 75c. Paper.

Buchheit, Otto. Pädagogische Tagespresse in Deutschland von der Reichsgründung bis zum weltkrieg, I871-1914. Mit einem Anhang: Gesamtverzeichnis der deutschsprachlichen pädagogischen Presse I87I1914. Triltsch, Würzburg, 1939. 258p. M. 6. (Zeitung und Leben, 57.)

Buenos Aires (province). Ministerio de governo. Biblioteca. Catalogo metodico de la biblioteca. Taller de impresiones oficiales, La Plata, 1939. 346p.

Carbia, Rómulo D. Historia crítica de la historiografía Argentina. Universidad de la Plata, La Plata, I939. 483p. \$I.80. (Facultad de humanidades y ciencias de la educación, de la Universidad de la Plata. Biblioteca humanidades, 22) Paper.

Carnoy, Albert. Dictionnaire étymologique du nom des commune de Belgique, y compris l'étymologie des principaux noms de hameaux et de rivières. Universitas, Louvain, 1939. T. I (in progress). 50 fr.

Cinti, Decio. Dizionario degli scrittori italiani classici, moderni e contemporanei. Sonzogno, Milano, 1939. 253p. L. 6.

Codignola, Ernesto. Pedagogisti ed educatori. illus., plates. Istituto editoriale italiano, Milano, 1939. 45 Ip. \$6.10. (Enciclopedia biografica e bibliografica "Italiana," Serie 38.)

Cosentini, Francesco. Code international du travail manuel et intellectuelle ... Dunod, Paris, 1939. 339p. \$2.40. Paper.

Debes, Ernest. Columbus-Weltatlas ... . Erweiterte Jubilaums Aus. II $8 \mathrm{Kt}$. S. mit 253 Haupt-und Nebenkt. 7. Aufl. Columbus, Berlin, 1939. 23Ip. M. 48.

Deutsche Liederkunde, Jahrbuch für Volkslied und Volkstanz. Jg. I. Voggen reiter, 
Potsdam, 1939. 247p. M. 6.20 or 7.50 . Deutsches Gynäkologen-Verzeichnis. 2. Aufl. Barth, Leipzig, 1939. 581р. M. 28.

Deutsches Städtebuch. Handbuch Städtische Geschichte. Kohlhammer, Stuttgart, 1939. Bd. I (in progress). Subscription price, M. I 20.

Dictionnaire des lettres françaises; moyen âge. Publié sous la direction de Georges Grente. Beauchesne, Paris, 1939. Fasc. I (Abilard-Athis et Prophilias). 93c.

Digel, O. Deutschtum in Ubersee und in den Kolonien; ein Schrifttums-Verzeichnis. Volk und Reich, Berlin, I939. 7Ip.

Documente und Urkunden zum Kriegsausbruch. Birkhäuser, Basel, I939. Fasc. I-3 (in progress). $7.75 \mathrm{fr}$.

Doutrepont, Georges. Histoire illustrée de la littérature française en Belgique. Précis méthodique. illus. Didier, Bruxelles, 1939. 378p. \$1.35.

Ehrencron-Müller, H. Anonym-og Pseudonym-Lexikon. Hagerup, Kфbenhavn, 1939. H. I-3 (in progress). $30 \mathrm{Kr}$., complete.

Ercole, Francesco. Risorgimento italiano. Istituto editoriale italiano, Milano, I939. Vol. I (in progress). \$6.10. (Enciclopedia biografica e bibliografica "Italiana," Serie 42).

Ernout, A. and Meillet A. Dictionnaire étymologique de la langue latine. Nouv. éd., revue. Klincksieck, Paris, I 939. I 84 p. \$II.25.

Förster, Meta and Zappe, W. M. Robert Browning-Bibliographie. Niemeyer, Halle, 1939. 35p. M. 4.

Franco, Alvaro. Dicionário inglês-português, português-inglês. Bertaso, Barcellos, 1939. 671, 396 p. $\$ 2.50$.

Giraud, Jeanne. Manuel de bibliographie littéraire pour les $\mathrm{vxi}^{\mathbf{e}}$, xviie, et $\mathrm{xviii}^{\mathrm{e}}$ siècles français, I92I-I935. J. Vrin, Paris, 1939. 302p. \$2.70. (Publications de la Faculté des lettres de I'Université de Lille, II.) Paper.

Grande encyclopédie de la Belgique et du Congo. illus., col. plates, maps. Wauthoz-Legrand, Bruxelles, I939. T. I (in progress). \$29.93, complete.

Grosse Brockhaus. 2. völlig neubearbeitete Ausgabe, in zwanzig Bänden und einem
Atlas. Brockhaus, Leipzig, I939. Bd. I (in progress). Subscription price, M. 20 or 25 .

Guia economica de Bolivia. Anuario no. I, ano 1939. Una enciclopedia de la economía nacional. "Fenix," La Paz, I939.

$\mathrm{H}$ andbuch der Münzkunde von Mittel-und Nordeuropa. Akademie Verlagsgesellschaft, Leipzig, I939. Bd. I, Lfg. I (in progress). Subscription price, M. I0.50.

Handbuch der schweizerischen Volkswirtschaft. Herausgegeben von der Schweizerischen Gesellschaft für Statistik und Volkswirtschaft. tables. A. G. Benteli, Bern, I939. 2v. $80 \mathrm{fr}$.

Handbuch des deutschen Schrifttums; herausgegeben von Franz Koch. plates (part col.). Akademischer Verlagsgesellschaft Athenaíon, Potsdam, I939. Bd. I, Lfg. I and Bd. 3, Lfg. I (in progress). 86c per $\mathrm{Lfg}$.

Handschriften der Staats-und UniversitätsBibliothek, Breslau. Harrassowitz, Leipzig, 1939. Bd. I, Lfg. I (in progress). M. 8 per Lfg. (Verzeichnis der Handschriften im deutschen Reich. Tl. I, Bd. I.)

Hebbe, P. M. Svenska lantbrukslitteraturen, I. Almvist \& Boktryckeri, Uppsala, 1939. 333p. \$3.40.

Herrle, Theo. Reclams Namenbuch; die wichtigsten deutschen und fremden Vornamen mit ihren Ableitungen und $\mathrm{Be}$ deutungen., 2. Aufl. Reclam, Leipzig, I939. 75p. 2 Ic.

International Institute of Agriculture. Bibliothèques agricoles dans le monde. . . . International Institute of Agriculture, Rome, I939. 3i Ip. \$I.50. Paper.

International Labour Office. Répertoire international des organisations cooperatives. I ${ }^{\text {me }}$ éd. International Labour Office, Geneva, 1939. I6op.

Jürgens, Adolph. Ergebnisse deutscher Wissenschaft. Eine bibliographische Auswahl ... der Jahre 1933-1938. Essener Verlagsanstalt, Essen, 1939. 782p. $\$ 8.75$.

Kern, Anton. Handschriften der Universitätsbibliothek Graz. Harrassowitz, Leipzig, I939. Bd. I, Lfg. I (in progress). M. 8 per Lfg. (Verzeichnis der Handschriften im deutschen Reich, Tl. 2, Bd. I) 
Kleberg, Tönnes. Svensk antiklitteratur. C. W. K. G., Lund, I939. I58p. 4.50 kr. (Skrifter av sv. Klassikerförb., I)

Klein, Karl K. Literaturgeschichte des deutschtums im Ausland. Bibliographisches Institut, Leipzig, I939. 475p. $\$ 5.25$.

Knaurs Welt-Atlas. Vollständig neue Ausgabe, 1939. illus., maps (part col.), tables. Knaur, Berlin, 1939. 272, 175p. 8 ic.

Köst, Ewald and Gerdi. Juristisches Wörterbuch. Dieterich'schen Verlagsbuchhandlung, Leipzig, 1939. 566p. \$1.65.

Krabbe, Wilhelm. Bibliographie. 3. Aufl. Einkaufhaus für Buchereien, Leipzig, 1939. 66p. 75c. (Veröffentlichungen der Berliner Bibliothekschule, H. I) Paper.

Lacroix, A. Inventaire des périodiques scientifiques des bibliotheques de Paris. Masson, Paris, I939. Fasc. I-6 (in progress).

Malatesta, Enzio. Armi ed armaioli. illus., plates. Istituto editoriale italiano, Milano, I939. 436p. L. 85. (Enciclopedia biografica e bibliografica "Italiana," Serie 50)

Medina, Jose Toribio. Bibliografia de la imprenta en Santiago de Chile desde sus origenes hasta febrero de 1817 ; adiciones y ampliaciones. illus., facsims. Universidad de Chile, Santiago de Chile, 1939. I 40p.

Mertens, J. Dictionnaire idzing-français suivi d'un aide-mémoire français-idzing. map. I. R. C. B., Bruxelles, I 939. 240p. $70 \mathrm{fr}$.

Mexico. Universidad nacional. Instituto de biologia. Bibliografía de los trabajos . . I930 a 1937. Instituto de biologia Chapultepic, I939. 64p. 25c. Paper.

Milan. Biblioteca della scuola di mistica fascista S. I. Mussolini. Bibliografia della civiltà del Fascismo. Nicola, Varese, 1939. I77p. L. 5. (Dottrina fascista. Sonderheft, marzo-maggio, 1939)

Minghetti, Aurelio. Ceramisti. illus., plates. Istituto editoriale italiano, $\mathrm{Mi}$ lano, I939. 45 Ip. \$6.Io. (Enciclopedia biografica e bibliografica "Italiana," Serie 4I)

Müller, Friedrich. Ortsbuch für das Land
Österreich. Post und Ortsbuchverlag, Wuppertal-Nachstebreck, I939. I42p. $\$ 2.85$.

Müller, Günther. Geschichte der deutschen Seele. Vom Faustbuch zu Goethes Faust. Herder, Freiburg, 1939. 494p. M. I2 or 14.20

Mummendey, Richard. Bibliographie der Gesamt-Zeitschriften-Verzeichnisse. B. Pick, Koln, 1939. 70p. M. 9.20. (Kölner bibliographische Arbeiten, 4)

Nachod, O. Bibliographie von Japon, 1906I935. . K. W. Hiersemann, Leipzig, 1939. 5v. M. 128.25 .

Neu, Wolfgang and Kummerlöwe, Hans. Bibliographie der zoologischen Arbeiten über die Türkei und ihre Grenzgebiete. Harrassowitz, Leipzig, 1939. 62p. \$1.67.

Niklas, $H$. and Ader, F. Düngung und Düngemittel. Heling, Leipzig, I939. 472p. M. 36. (Literatursammlung aus dem Gesamtgebiet der Agrikulturchemie. Erg. Bd. zu Bd. 4)

$\emptyset$ ksnevad, Reidar. Frankrike i norsk litteratur. En bibliografi. Norvège-France, Oslo, 1939. 159p. Io kr.

Olivares Figueroa, R. Nuevos poetas venezolanos (notas críticas). Elite, Caracas, 1939. I8op. Bs. 0.5o. (Cuadernos literarios de la "Asociación de escritores venezolanos," I6)

Pazzini, Adalberto. Medicina; bibliografia di storia della medicina italiana. Istituto editoriale italiano, Milano, I939. Vol. I (in progress). \$6.1o. (Enciclopedia biografica e bibliografica "Italiana," Serie 3I)

Quien es quien en la Argentina; biografías contemporáneas, año 1939. Kraft, Buenos Aires, 1939. 456p. 24 pesos.

Reichsgesetzblatt; systematische übersicht uber 72. Jahrgänge Reichsgesetzblatt I867-1938). I6.Aufl. Kohlhammer, Berlin, 1939. 132p. 86c.

Ridolfi, R. Bibliografia delle opere del Savonarola. tables. Conti, Firenze, 1939. I72p.

Riecke, E. Deutsches Dermatologen-Verzeichnis. 2.Aufl. Barth, Leipzig, 1939. 314p. M. 25.

Rost, H. Bibel im Mittelalter. Seitz, Augsburg, 1939. 428p. M. I8.50 or 22. Salvini, Roberto. Giotto; bibliografia. Pa- 
lombi, Roma, 1939. 4I5p. L. 65. (R. Ist. d'archeologia e storia dell'arte. Bibliog. e cataloghi, 4)

Sanchez Roig, M. Bibliografia de la prensa medica cubana, I840-1885. "Propagandista," Habana, 1939. 25p.

Sanna, G. Bibliografia generale dell'età romana imperiale. Nuova Italia, Firenze, I939. Vol. I, Parte generale, Fasc. I, p. I-I23. \$2.40. Paper.

Schuh, Willi and Refardt, E. Schweizer Musikerlexikon. Atlantis, Zürich, 1939. 220p. 7 fr. (Schweizer Musikbuch, II)

Schweizerischer Buchhändlerverein Livres suisses. Schweizerische Landesausstellung, Zürich, I939. 232p.

Schweizerisches Recht. Schweizerischer Buchhändlerverein, Frauenfeld, 1939. 20Ip. 85c. (Schweizerische Bücherkataloge)

Selección bibliografia de obras alemanas en traducción espanola y portuguesa. Iberoamer. Inst., Berlin, 1939. I $47 \mathrm{p}$.

Soenke, J. Reden des Führers [Hitler] nach der Machtübernahme. Eher, Berlin, 1939. 192p. 79c. (Nationalsozialistische Bibliographie, Beih. 2)

Statistisches Taschenjahrbuch der Weltwirtschaft, Produktion, Aussenhandel, Verkehr. Rödiger, Berlin, 1939. M. 2.50.

Strom, Hans. Wörterbuch für die Waffen-Munitions- und Sprengstoffindustrie. Deu tsch-englisch - $\mathrm{französisch-italienisch-}$ spanisch. 2. Aufl. Strom, Suhl, I939. 440p. M. 12.
Stümke, Hans. Bibliographie der internationalen Kongresse und Verbände. Bd. I : Medizin. Harrassowitz, Leipzig, 1939. 28Ip. \$9.

Svensk litteraturhistorisk bibliografi, 19001935. Svenska litteratursällskapet, Uppsala, 1939. H. I (in progress). \$I.I4. (Skrifter utgivna av svenska litteratursällskapet, 29: I)

Tuymelaar, C. T. and Lindock, J. van. Pseudoniemen uit Nederlandsche en vreemde Literatur. Born, Assen, 1939. 64p. Fl. 1.40.

Uva, Nicola. Educatori. Dizionario biobibliografico dei moderni e contemporanei. Martini, Bari, 1939. 339p. L. I8.

Van Huffel, A. J. Nederlandsche Schrijvers in Vertaling (van Marcellus Emants tot Jan Eekhout). Brill, Leiden, 1939. 89p. $70 c$.

Vilbig, F. Schrifttumsverzeichnis zum Lehrbuch der Hochfrequenztechnik. 2. Aufl. Akademische Verlagsgesellschaft, Leipzig, 1939. 57p. M. 7 or 8 .

Wais, Kurt. Gegenwartsdichtung der europäischen Völker; herausgegeben mit I04 Dichterbildnissen. Junker und Dünnhaupt, Berlin, 1939. 567p. M. I4 or 16.

Weis, Erwin. Bibliographie zur Geschichte der Vereinigten Staaten im Weltkrieg. Weltkriegsbücherei, Stuttgart, 1939. I9ı. (Bibliographische Vierteljahrshefte der Weltkriegsbücherei, H. 20-22)

Zavatti, Silvio. Dizionario generale degli esploratori. Sonzogno, Milano, I939. 267p. 


\section{Publications of Interest to Adminis- trative Officers of Higher Institutions}

THE LIST that follows has been compiled by Clara Esther Deering and Carrie E. 1 Meares of Teachers College Library, Columbia University, to serve as a guide to the associations and publications in the field of higher education. It is a selected list of publications, regularly issued, which deal with problems of administration in colleges and universities. In the references to associations the name of the president is given first followed by that of the secretary. Unless an address is given for the association, communicate with the secretary in regard to securing proceedings or reports. The names of officers and the place and date of annual meetings of the associations are given in the United States Office of Education, Educational Directory, Part 4: Educational Associations and Directories (Bulletin No. I).

\section{Association Yearbooks, Proceedings and Reports}

American Association of University Professors.

744 Jackson Place, Washington; M. H. Inghram, University of Wisconsin, Madison; R. E. Himstead, 744 Jackson Place, Washington.

Annual proceedings published in their Bulletin.

American College Personnel Association. Helen M. Voorhees, Mt. Holyoke Collge, South Hadley, Mass.; Harriet E. O'Shea, Purdue University, Lafayette, Ind.

Proceedings.

American College Publicity Association. Eleanor R. Mosely, Boston University, Boston; Russell Alexander, DePauw University, Greencastle, Ind.

Annual report.

American Student Health Association. Dr. Charles E. Shepard, Stanford University, Calif.; Dr. Ruth E. Boynton, University of Minnesota, Minneapolis.

Annual proceedings.

Association of American Colleges. 19 W. 44 Street, New York City. Meta Glass, Sweet Briar College, Sweet Briar, Va.; Guy E. Snavely, 19 W. 44 Street, New York City.

Annual proceedings, published in the March issue of their Bulletin.
Association of American Universities.

F. K. Richmyer, secretary, Cornell University, Ithaca, N.Y.

Journal of Proceedings and Addresses, University of Chicago Press. (Annual)

Association of College Unions.

J. E. Patrick, Indiana University, Bloomington; Paul B. Hartenstein, University of Pennsylvania, Philadelphia.

Annual report, University of Pennsylvania, Philadelphia.

Association of Colleges and Secondary Schools for Negroes.

Rufus E. Clement, Atlanta University, Atlanta; L. S. Cozart, Barber-Scotia Junior College, Concord, N.C.

Annual proceedings.

Association of Governing Boards of State Universities and Allied Institutions.

S. J. Galvin, Sheffield, Iowa; D. W. Springer, 209 Woodward Building, Washington.

Proceedings.

Association of Land-Grant Colleges and Universities.

J. A. Burruss, Blacksburg, Va.; Thomas Cooper, University of Kentucky, Lexington.

Proceedings.

Association of Urban Universities.

Eugene A. Colligan, Hunter College of the City of New York, New York City; 
Roscoe M. Ihrig, Carnegie Institute of Technology, Pittsburgh.

Annual proceedings.

Carnegie Corporation of New York. 522 Fifth Avenue, New York City. F. P. Keppel, 522 Fifth Avenue, New York City; R. M. Lester, 522 Fifth Avenue, New York City.

Annual report.

Carnegie Foundation for the Advancement of Teaching.

522 Fifth Avenue, New York City. Walter A. Jessup, 522 Fifth Avenue, New York City; H. J. Savage, 522 Fifth Avenue, New York City.

Annual report.

College Entrance Examination Board.

43I W. I 7 Street, New York City. R. M. Gummere, Harvard University, Cambridge, Mass.; G. W. Mullins, 43I W. I 7 Street, New York City.

Annual report.

Conference of Negro Land-Grant Colleges. R. B. Arwood, Kentucky State College, Frankfort; William H. Bell, Alcorn A. and $M$. College, Alcorn, Miss.

Annual proceedings.

Eastern Association of College and University Business Officers.

G. D. Crofts, University of Buffalo, Buffalo; H. S. Ford, Massachusetts Institute of Technology, Cambridge, Mass.

Minutes of the annual meeting.

Eastern Association of College Deans and Advisers of Men.

Frank G. Lankard, Drew University, Madison, N.J.; Edward M. Twitmyer, Girard College, Philadelphia.

Annual proceedings.

Eastern College Personnel Officers Association.

Emory E. Grayson, Massachusetts State College, Amherst; L. Alice Ramsay, Connecticut College, New London.

Proceedings.

Middle States Association of Colleges and Secondary Schools.

William W. Comfort, Haverford Col- lege, Haverford, Pa.; Karl G. Miller, University of Pennsylvania, Philadelphia. Annual proceedings.

National Association of Collegiate Deans and Registrars in Negro Schools.

A. L. Kidd, Florida A. and M. College, Tallahassee; S. Herbert Adams, Johnson C. Smith University, Charlotte, N.C. Annual proceedings.

National Association of Deans and Advisers of Men.

James F. Findlay, University of Oklahoma, Norman; F. H. Turner, University of Illinois, Urbana.

Annual proceedings.

National Association of State Universities in the United States of America.

A. G. Crane, University of Wyoming, Laramie; H. G. James, Ohio University, Athens.

Annual transactions and proceedings.

National Education Association. American Association of Teachers Colleges.

Charles C. Sherrod, State Teachers College, Johnson City, Tenn.; Charles W. Hunt, State Normal School, Oneonta, N.Y.

Yearbook.

National Society for the Study of Education. Bess Goodykoontz, Federal Security Agency, United States Office of Education, Washington; Guy M. Whipple, Clifton, Mass.

Yearbook, Public School Publishing Co., Bloomington, Ill.

National Society of College Teachers of Education.

Louis A. Pechstein, University of Cincinnati, Ohio; Fowler D. Brooks, DePauw University, Greencastle, Ind.

Yearbook.

National University Extension Association. B. C. Riley, University of Florida, Gainesville; W. S. Bittner, Indiana University, Bloomington.

Annual proceedings.

Northwest Association of Secondary and Higher Schools.

B. K. Farnsworth, State Capitol, Salt 
Lake City, Utah; Paul S. Filer, 322 Columbia Building, Spokane, $\mathrm{W}$ ash.

Annual proceedings.

Southern Association of Colleges and Secondary Schools.

P. A. Roy, Loyola University, New Orleans, La.; Shelton Phelps, Winthrop College, Rock Hill, S.C.

Annual proceedings published in their Quarterly.

Supervisors of Student Teaching.

Edith E. Beechel, Ohio University, Athens; J. W. Carrington, State Normal University, Normal, Ill.

Annual proceedings.

\section{Periodicals}

American Teacher. Published by the American Federation of Teachers, 506 S. Wabash Avenue, Chicago. George T. Guernsey, ed. 9 issues. $\$ 2.50$ a year.

Association of American Colleges Bulletin. Published by the Association of American Colleges, 19 W. 44th Street, New York. Guy E. Snavely, ed. 4 issues. $\$_{3}$ a year.

Bulletin of the American Association of University Professors. Published by the American Association of University Professors, 744 Jackson Place, Washington. R. E. Himstead, ed. 5 issues. $\$ 3$ a year.

College and Research Libraries. Published by the American Library Association, 520 N. Michigan Avenue, Chicago. A. F. Kuhlman, ed. 4 issues. $\$ 3$ a year.

College Publicity Digest. Published by the American College Publicity Association, Midland College, Freemont, Neb. W. E. Reck, ed. Monthly. \$2 a year.

Educational Record. Published by the American Council on Education, 744 Jackson Place, Washington. C. S. Marsh, ed. 4 issues. $\$ 2$ a year.

Journal of Higher Education. Published by the Bureau of Educational Research, Ohio State University, Columbus. W. W. Charters, ed. 9 issues. $\$ 3$ a year.

Journal of the American Association of Collegiate Registrars. Published by the
American Association of Collegiate Registrars. M. E. Gladfelter, ed. Publication office: 450 Ahnaip St., Menasha, Wis. 4 issues. $\$ 3$ a year.

Journal of the American Association of University Women. Published by the American Association of University Women, 1634 Eye Street, N.W., Washington. Ruth Wilson Tryon, ed. 4 issues. $\$ \mathrm{I}$ a year.

Journal of the National Association of Deans of Women. Published by the Department of Deans of the National Education Association, 1201 16th Street, N.W., Washington. Ruth Strang, ed. 4 issues. $\$ 2.50$ a year.

Junior College Journal. Published by the American Association of Junior Colleges, 744 Jackson Place, Washington. Walter C. Eells, ed. 8 issues. $\$ 3$ a year.

North Central Association Quarterly. Published by the North Central Association of Colleges and Secondary Schools, Room 1439, University Elementary School Building, University of Michigan, Ann Arbor. Calvin O. Davis, ed. 4 issues. $\$ 5$ a year.

Quarterly Review of Higher Education Among Negroes. Published by Johnson C. Smith University, Charlotte, N.C. H. L. McCrorey, ed. 4 issues. \$2 a year.

Southern Association Quarterly. Published by the Southern Association of Colleges and Secondary Schools. Duke University Press, College Station, Durham, N.C. Holland Holton, ed. 4 issues. $\$ 4$ a year. School and Society. Published by the Science Press, Lancaster, Pa. for the Society for the Advancement of Education, Inc., 525 W. 120th Street, New York. William C. Bagley, ed. Weekly. \$5 a year.

Teacher-Education Journal. Published by the Eastern Association of Professional Schools for Teachers, 4I Press Annex Building, New York University, 26 Washington Place, New York. Publication office: George Banta Publishing Co., 450 Ahnaip Street, Menasha, Wis. Ambrose L. Suhrie, ed. 4 issues. $\$ \mathbf{I}$ a year. 